\title{
Rheology of Savannah River Site Tank 42 Radioactive Sludges (U)
}

by

B. C. $\mathrm{Ha}$

Westinghouse Savannah River Company

Savannah River Site

Aiken; South Carolina 29808

N. E Bibler:

A document prepared for EMERGING TECHNOLOGIES IN HAZARDOUS WASTE VIII I\&EC SPECIAL SYMPOSIUM at Birmingham from 09/09/96 - 09/11/96.

DOE Contract No. DE-AC09-89SR18035

This paper was prepared in connection with work done under the above contract number with the U.S.

Department of Energy. By acceptance of this paper, the publisher and/or recipient acknowledges the U.S. Government's right to retain a nonexclusive, royalty-free license in and to any copyright covering this paper, along with the right to reproduce and to authorize others to reproduce all or part of the copyrighted paper. 


\section{DISCLAIMER}

Portions of this document may be illegible in electronic image products. Images are produced from the best available original document. 


\section{DISCLAIMER}

This report was prepared as an account of work sponsored by an agency of the United States Government. Neither the United States Government nor any agency thereof, nor any of their employees, makes any warranty, express or implied, or assumes any legal liability or responsibility for the accuracy, completeness, or usefulness of any information, apparatus, product, or process disclosed, or represents that its use would not infringe privately owned rights. Reference herein to any specific commercial product, process, or service by trade name, trademark, manufacturer, or otherwise does not necessarily constitute or imply its endorsement, recommendation, or favoring by the United States Government or any agency thereof. The views and opinions of authors expressed herein do not necessarily state or reflect those of the United States Government or any agency thereof.

This report has been reproduced directly from the best available copy.

Available to DOE and DOE contractors from the Office of Scientific and Technical Information, P.O. Box 62, Oak Ridge, TN 37831; prices available from (615) 576-8401.

Available to the public from the National Technical Information Service, U.S. Department of Commerce; 5285 Port Royal Road, Springfield, VA 22161. 
PREPRINT EXTENDED ABSTRACT

Presented at the I\&EC Special Symposium

American Chemical Society

Birmingham, AL., September 9-11, 1996

\title{
RHEOLOGY OF SRS TANK 42 RADIOACTIVE SLUDGES
}

\author{
B. C. Ha and N. E. Bibler \\ Savannah River Technology Center \\ Westinghouse Savannah River Company \\ Aiken, South Carolina 29808
}

Knowledge of the rheology of the radioactive sludge slurries at the Savannah River Site (SRS) is necessary in order to ensure that they can be retrieved from waste tanks and processed for final disposal. At Savannah River Site (SRS), Tank 42 sludge represents one of the first HLW radioactive sludges to be vitrified in the Defense Waste Processing Facility (DWPF). The rheological properties of unwashed Tank 42 sludge slurries at various solids concentrations were measured remotely in the Shielded Cells at the Savannah River Technology Center (SRTC) using a modified Haake Rotovisco viscometer.

Rheological properties of Tank 42 radioactive sludge were measured as a function of weight percent total solids to ensure that the first DWPF radioactive sludge batch can be pumped and processed in the DWPF with the current design bases. The Tank 42 sludge sample, as received, contained $27 \mathrm{wt} \%$ total solids. The weight percent total solids were adjusted by dilution with water or by concentration through drying.

The yield stress and consistency of the sludge slurries were determined by assuming a Bingham plastic fluid model. The general shape of the sludge slurry flow curve data supports the Bingham plastic fluid approximation (Figure 1). Yield stress and consistency were determined using the intercept and slope of the flow curves, respectively. Figure 2 shows the apparent viscosities as a function of shear rates for Tank $42 \mathrm{HLW}$ radioactive sludge slurry containing $34 \mathrm{wt} \%$ total solids.

The yield stresses were $10,11,63,90$ and 381 dynes $/ \mathrm{cm}^{2}$ at $8,17,23,27$ and 34 weight percent total solids, respectively. The apparent viscosities were $10,20,35,45$ and 150 centipoises at $300 \mathrm{sec}^{-1}$ shear rate, respectively. These results agreed with results of non-radioactive sludge simulants. For example, a $15 \mathrm{wt} \%$ total solids non-radioactive sludge simulant has a yield stress of $12 \mathrm{dynes} / \mathrm{cm}^{2}$, and an apparent viscosity of 12 centipoises at $300 \mathrm{sec}^{-1}$ shear rate.

Rheological properties of SRS Tank 21 radioactive sludge has been studied previously, as reviewed in reference 1. It was found that below $14 \mathrm{wt} \%$ insoluble solids, the yield stress of Tank 21 sludge was less than 40 dynes $/ \mathrm{cm}^{2}$, and the consistency was less than 10 centipoises. ${ }^{1}$ This is consistent with what has been observed with Tank 51 sludge containing less than $18 \mathrm{wt} \%$ total solids. 1 Tank 42 sludge containing less than $17 \mathrm{wt} \%$ total solids, or $13 \mathrm{wt} \%$ insoluble solids, had only a quarter of the yield stress, 10 dynes $/ \mathrm{cm}^{2}$, but twice the consistency, 20 centipoises. 


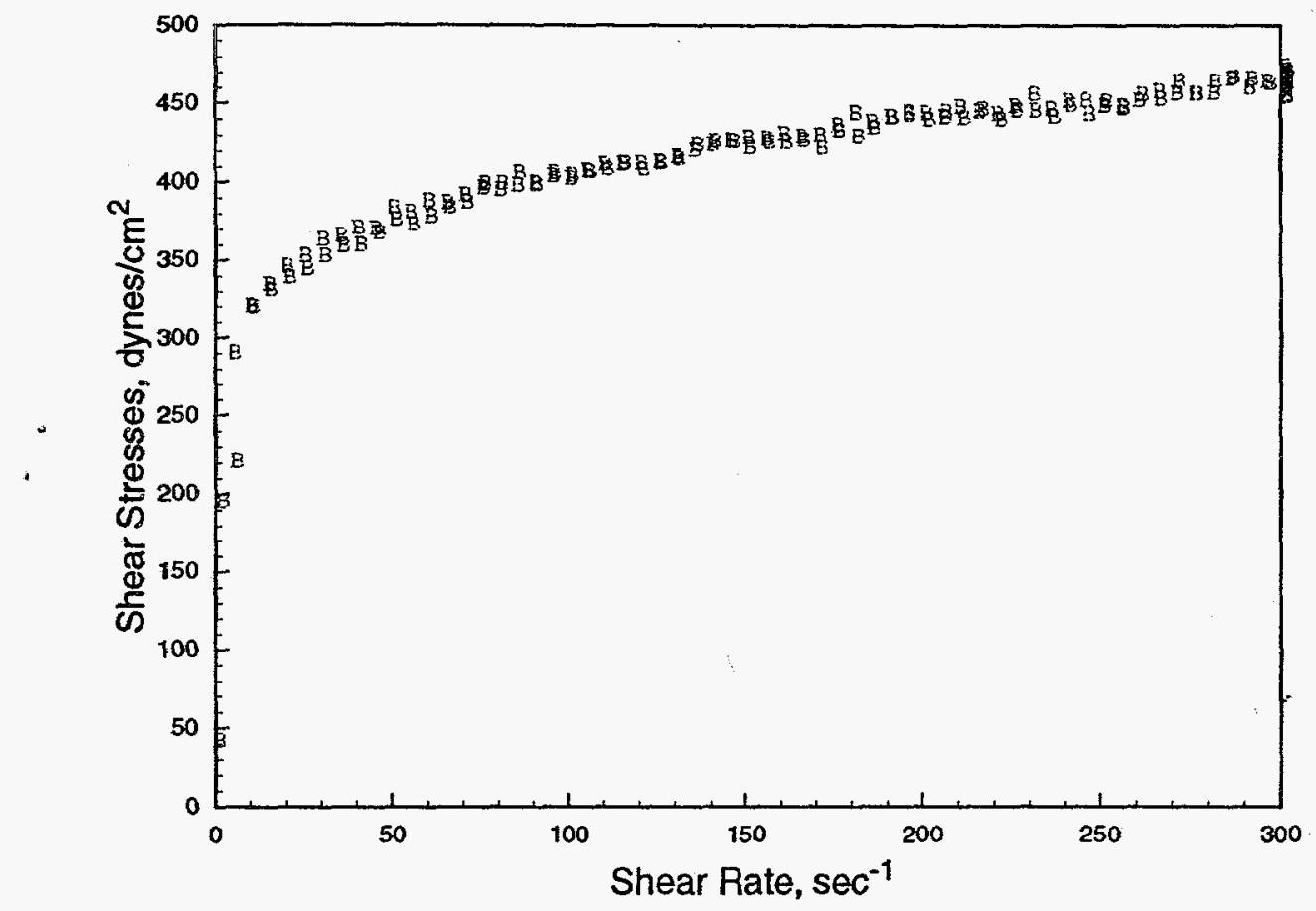

Figure 1. Tank 42 Sludge Containing $34 \mathrm{wt} \%$ Total Solids Behaves as a Bingham Plastic Fluid.

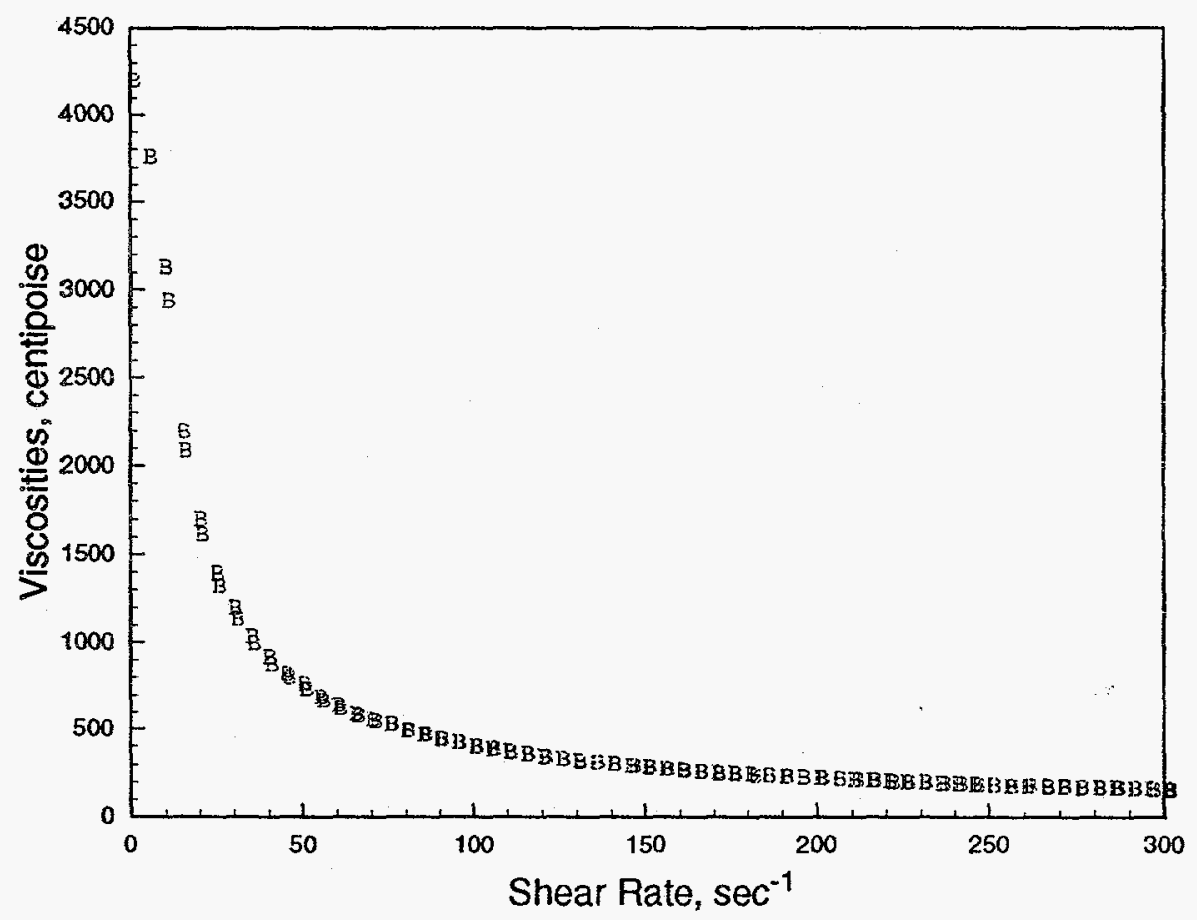

Figure 2. Rheology Behavior of Tank 42 Sludge Containing $34 \mathrm{wt} \%$ Total Solids.

It was also also found that, at 44 volume $\%$ total solids (or $17 \mathrm{wt} \%$ insoluble solids), the yield stress of Tank 21 radioactive sludge was in the range of 80 to 120 dynes $/ \mathrm{cm}^{2}$, and the consistency was from 15 to $20 \mathrm{cp} .1$ The yield stress results compared very well to those of Tank 51 sludge. ${ }^{1}$ However, Tank 42 
sludge has a higher consistency, but a lower yield stress at a comparable solids concentration. Both, Tank 51 and Tank 21 radioactive sludges have been washed, but Tank 42 sludge was not washed at the time the rheology was measured. The differences in their rheological properties can be attributed to the sludge washing process.

During the Extended Sludge Processing (ESP), the concentrations of sodium, nitrite, and nitrate in the DWPF sludge feed are reduced to the appropriate levels to ensure the processability of the glass and to minimize $\mathrm{NO}_{\mathrm{X}}$ emissions and production of ammonium nitrate in the vent system. Hay and Bibler ${ }^{2}$ reported that the settling rate of Tank 42 sludge increased as density of the wash water decreased with each wash cycle. The higher consistency of Tank 42 sludge slurry compared to those of Tank 51 and 21 washed sludges is due to the higher density of the supernate. Viscosity was correlated to a function of the square root of density by Thomas et. al. ${ }^{3,4}$ for associated and nonassociated liquids. Although the viscosity model $^{3,4}$ was developed for a liquid mixture rather than a solid-liquid slurry, it indicates that density has an additive effect on the consistency of the unwashed sludge compared to the washed sludge slumies.

Furthermore, the morphology of the wash sludge slurries was also changed during the wash cycles of the ESP process. Lower density and better packing of solid particles in the settled washed sludge slurries increases the settling rate as indicated in Hay and Bibler's paper ${ }^{2}$, and the yield stress as evidenced from the lower yield stress of Tank 42 unwashed sludge compared to washed Tank 51 and Tank 21 sludge slurries.

\section{ACKNOWLEDGMENTS}

This paper was prepared in connection with work done under Contract no. DE-AC0989SR18035 with the U. S. Department of Energy.

\section{REFERENCES}

1. Ha, B. C., "Rheology of Savannah River Site Tank 51 HLW Radioactive Sludge," Waste Management ' $93,2,1071-1073$ (1993).

2. Hay, M. S. and Bibler, N. E., "A Laboratory Study of Washing of SRS High-Level Waste Radioactive Sludge - Evidence for Insoluble Sodium and Cesium-137," Proceedings of the International Topical Meeting on Nuclear and Hazardous Waste Management Spectrum '94, 828832 (1994).

3. Thomas, L. H., Meatyard, R., Smith, H., and Davis, G. H., Journal of Chemcal Engineering Data, 24 (3), 161-164 (1979).

4. Thomas, L. H., Chem. Eng. J., 11, 201 (1976). 